\begin{tabular}{|l|l|l||}
\hline \multicolumn{2}{|c|}{ PublisherInfo } \\
\hline \hline PublisherName & $:$ & BioMed Central \\
\hline \hline PublisherLocation & $:$ & London \\
\hline \hline PublisherImprintName & $:$ & BioMed Central \\
\hline \hline
\end{tabular}

\title{
Id and aging
}

\begin{tabular}{|l|l|l||}
\hline \multicolumn{2}{|c|}{ ArticleInfo } \\
\hline \hline ArticleID & $:$ & 4133 \\
\hline \hline ArticleDOI & $:$ & $10.1186 /$ gb-spotlight-20010629-01 \\
\hline \hline ArticleCitationID & $:$ & spotlight-20010629-01 \\
\hline \hline ArticleSequenceNumber & $:$ & 204 \\
\hline \hline ArticleCategory & $:$ & Research news \\
\hline \hline ArticleFirstPage & $:$ & 1 \\
\hline \hline ArticleLastPage & $:$ & 2 \\
\hline \hline & & RegistrationDate : 2001-06-29 \\
ArticleHistory & $:$ & OnlineDate \\
\hline \hline ArticleCopyright & $:$ & BioMed Central Ltd2001 \\
\hline \hline ArticleGrants & $:$ & \\
\hline \hline ArticleContext & $:$ & 130592211 \\
\hline \hline
\end{tabular}




\section{Jonathan B Weitzman}

Email: jonathanweitzman@hotmail.com

Id1 is one of a family of helix-loop-helix (HLH) proteins that inhibits transcription by sequestering other HLH factors. It has been implicated in the regulation of cell growth and cellular aging. In the July 3 Proceedings of the National Academy of Sciences, Alani et al. provide genetic evidence supporting a role for Id1 in preventing cell aging (Proc Natl Acad Sci USA 2001, 98:7812-7816). They found that fibroblasts from Id1-null mice display premature senescence with increased expression of the cell-cycle regulators p16/INK4a, cyclin D1 and cyclin E. They show that Id1 specifically inhibits transcription of the $p 16 / I N K 4 a$ promoter, but does not affect p19/Arf regulation (although $\mathrm{p} 19$ is transcribed from the same locus as p16). Two E-box motifs in the p16/INK4a promoter are essential for Id1 repression. Finally, they report increased expression of p16/INK4a in vivo, in the ventral telencephalon of IdI-null embryos. The authors speculate that Id1 repression may be responsible for deregulation of p16 expression in the early stages of tumorigenesis.

\section{References}

1. ID helix-loop-helix proteins in cell growth, differentiation and tumorigenesis

2. Proceedings of the National Academy of Sciences, [http://www.pnas.org]

3. High incidence of T-cell tumors in E2A-null mice and E2A/Id1 double-knockout mice. 